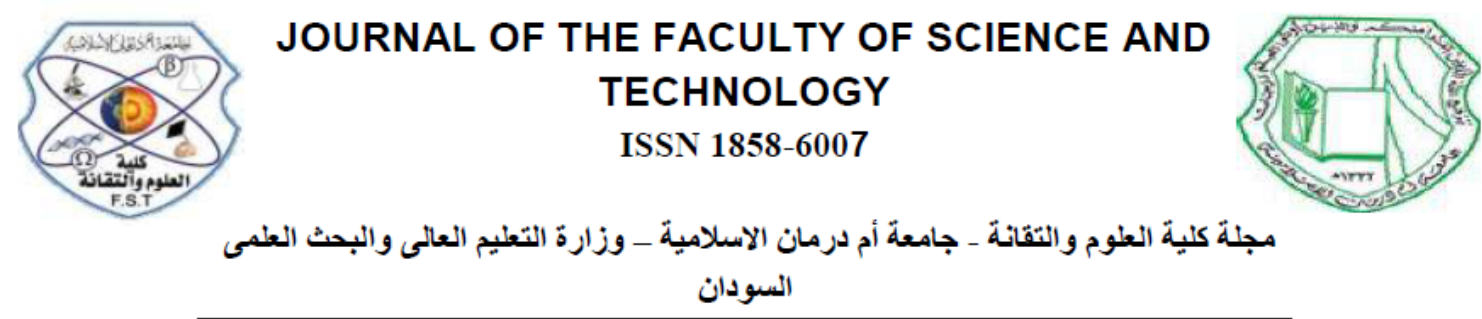

Research article

\title{
Physico-chemical Characteristics and Heavymetal contents in Soil of South West EL-Fasher City,Western Sudan
}

\author{
${ }^{1}$ Fatima Siddig Adam Abdel Wahed, ${ }^{1 *}$ HatilHashim EL-Kamali
}

${ }^{1}$ Department of Chemistry, Faculty of Education, EL-Fashir University

${ }^{2}$ Department of Botany, Faculty of Science and Technology, Omdurman Islamic University

\begin{abstract}
The objectives of this study were to assess levels of trace and heavy elements in South west EL-Fasher cityin North Darfur soils and to provide information regarding accumulation of these metalsin top and sub-soils and to determine the most important soil factors (chemical and physical) which influence trace and heavy elements concentrations in soil.Top and sub-soil samples were taken at various locations in South west EL-Fasher city. The soil characterization was carried out for parameters like pH, E.C, O.C, M.C, soil texture, and trace and heavy elements ( $\mathrm{Cd}, \mathrm{Co}, \mathrm{Cr}, \mathrm{Cu}, \mathrm{Fe}, \mathrm{Mn}, \mathrm{Mo}, \mathrm{Ni}, \mathrm{Pb}$ and $\mathrm{Zn}$ ). The results obtained in this research work provides documentation of the relationship between physicochemical properties and heavy metals concentrations in soils of North Darfur. The $\mathrm{pH}$ was found to be slightly alkaline. The values of E.C indicated that all samples of the soils are non-saline. $\mathrm{Fe}, \mathrm{Mn}, \mathrm{Cr}, \mathrm{Zn}$ and $\mathrm{Cu}$ were distributed in very high concentrations compared to other metals. This study will help the industrial section and can be benefit from it for commercial purposes.There were obvious differences in correlation coefficients among the selected criteria $165.6 \%$ from total number of correlated between $\mathrm{pH}$ and some other selected physicochemical characteristics, whereas $42.3 \%$ from the total number were positive correlated between soil texture and some other selected physicochemical characteristics. This study can serves as a database of trace and heavy elements build-up in soil, allowing preventive actions to be taken.
\end{abstract}

Keywords:Heavy metals, physicochemical , Soil, South west EL-Fashir city, Western Sudan

\section{Introduction}

Heavy metals in high concentrations of soil has become a major health risk throughout the world. The increase in levels of heavy metals in soils led to deterioration of soil health(Rayment GE2002) (Kaur M., et al 2014).Heavy metals content in soils are dependent on the soil physicochemical properties (Sinha S, (2006). 
Heavy elements enter into the environment mainly via three routes : (i) Deposition of atmospheric particulate (ii) Disposal of metal enriched sewage sludges and sewage effluents and (iii) By-products from metal mining process. Trace and heavy metal concentration in the soils is a major concern because of their toxicity and threat to human life and the environment. Heavy metal studies are necessary to evaluate both soil/sediment and ground water contamination. Heavy metals and other trace elements are important for proper functioning of biological systems and their deficiency or excess could lead to a number of disorders.

This study was undertaken to provide a general assessment of the physicochemical characteristics and levels of trace and heavy elements in the South west of North Darfur soils.

\section{Materials and Methods}

\section{Study site description and soil sampling}

North Darfur occupies more than half of the territory of the Darfur region, and includes part of the Jebel Marrah. The northern part is entirely desert. To the south there is slightly more rainfall with the eastern side being plains with the low sandy hills, while the volcanic Marrah Mountains occupy most of the western side of the south.

North Darfur is bounded on the northwest by Libya, on the north by Northern State, on the east by the Northern State and North Kordofan, on the south-east by south kordofan, on the south by South Darfur, and on the west by west Darfur and the Republic of Chad.

Soil samples were collected from sout west EL-Fashir city , North Darfur State , Western Sudan in March - April 2015, from the 0-20 $\mathrm{cm}$ depth (approximately the A horizon) and the B horizon (approximately the $20-40 \mathrm{~cm}$ depth).

\section{Analysis of soil physico-chemical properties}

\section{Soil Texture}

The hydrometer method using soil dispersing stirrer was used for soil texture analysis. Once the percentage of sand, silt, and clay is measured, the soil may be assigned a textural class using the Table of textural soil types (Forest Service Handbook. Washington, DC, 1960, Department of Agriculture, US).

\section{Chemical Analysis of the Soil}

The $\mathrm{pH}$ of the soil was measured in a soil water suspension (1:2, soil : water). Organic carbon content $(\%)$ of the soil was determined by Black method $(1965)^{5}$ using $1 \mathrm{~g}$ soil. Organic matter $(\%)$ was determined by multiplying the value of organic carbon by 1.724 (van bemmelen factor). Saturation Percentage (SP) was determined on a soil paste made with distilled water. $\mathrm{pH}$ and Electrical conductivity (EC) were determined from saturated soil extract (Piper, 1950).

Soil moisture content was determined by oven drying method (Allen,1974). The soil organic carbon analysis was performed according to standard procedure (Richards, 1954).

\section{Determination of trace and heavy elements}

One gram soil sample was decomposed with a HF-HClO4-HNO3 mixture followed by Atomic Absorption Spectrophotometry (AAS) for chromium, cobalt, copper, iron, lead, manganese, molybdenum, nickel, zinc and cadmium. 


\section{Statistical Analysis}

Statistical analysis, such as descriptive statistics, correlation coefficients were performed using SPSS 20.0 Software for Windows .

\section{RESULTS AND DISCUSSION}

This research work provides documentation of the relationship between physico -chemical properties and heavy elements in soils of North Darfur. Table 1 shows the descriptive statistics for the recorded trace and heavy elements contents in the Top- and Sub-soils of study area in North Darfur. Means and standard deviation used to describe central tendency and variation of the data.

The results of physico-chemical analysis (viz. pH, EC, O.C, M.C, soil texture : clay, silt and sand) and selected trace /heavy element concentrations of randomly selected soil samples collected from top and subsoil layers of South west EL-Fasher, North Darfur are provided in Table 1.

Table 1.Descriptive statistics- Topsoil and Subsoil

\begin{tabular}{|c|c|c|}
\hline Parameters & $\begin{array}{c}\text { Topsoil } \\
\text { Mean } \\
\text { SD }\end{array}$ & $\begin{array}{l}\text { Subsoil } \\
\text { Mean } \\
\text { SD }\end{array}$ \\
\hline pH & $\begin{array}{l}7.529 \\
0.158\end{array}$ & $\begin{array}{l}7.464 \\
0.109\end{array}$ \\
\hline E.C & $\begin{array}{l}0.535 \\
0.292\end{array}$ & $\begin{array}{l}0.437 \\
0.111\end{array}$ \\
\hline O.C & $\begin{array}{l}0.842 \\
0.220\end{array}$ & $\begin{array}{l}0.806 \\
0.080\end{array}$ \\
\hline M.C & $\begin{array}{l}3.21 \\
0.291\end{array}$ & $\begin{array}{l}3.202 \\
1.193\end{array}$ \\
\hline Clay & $\begin{array}{l}29.836 \\
8.676\end{array}$ & $\begin{array}{l}31.113 \\
1.274\end{array}$ \\
\hline Silt & $\begin{array}{l}26.391 \\
3.718\end{array}$ & $\begin{array}{l}28.309 \\
6.193\end{array}$ \\
\hline Sand & $\begin{array}{l}43.773 \\
8.058\end{array}$ & $\begin{array}{l}40.573 \\
5.997\end{array}$ \\
\hline Cd & $\begin{array}{l}0.563 \\
0.240\end{array}$ & $\begin{array}{l}0.8342 \\
88 \\
0.431\end{array}$ \\
\hline Co & $\begin{array}{l}0.05 \\
7.418\end{array}$ & $\begin{array}{l}0.05 \\
7.418\end{array}$ \\
\hline $\mathrm{Cr}$ & $\begin{array}{l}58.406 \\
16.699\end{array}$ & $\begin{array}{l}75.202 \\
5 \\
8.262 \\
\end{array}$ \\
\hline $\mathrm{Cu}$ & $\begin{array}{l}23.61 \\
5.826\end{array}$ & $\begin{array}{l}29.646 \\
25 \\
3.027\end{array}$ \\
\hline $\mathrm{Fe}$ & $\begin{array}{l}29845.125 \\
6122.042\end{array}$ & $\begin{array}{l}35029 . \\
25\end{array}$ \\
\hline
\end{tabular}




\begin{tabular}{|l|l|l|}
\hline & & $\begin{array}{l}5188.2 \\
36\end{array}$ \\
\hline Mn & 508.975 & 636.06 \\
& 137.484 & 25 \\
& & 60.810 \\
\hline Mo & 2.180 & 2.4595 \\
& 1.348 & 0.882 \\
\hline $\mathbf{N i}$ & 10.857 & 22.596 \\
& 15.510 & 712 \\
& & 24.050 \\
\hline $\mathbf{P b}$ & 10.857 & 16.252 \\
& 3.583 & 5 \\
& & 2.500 \\
\hline $\mathbf{Z n}$ & 26.334 & 50.638 \\
& 18.292 & 75 \\
& & 30.748 \\
\hline
\end{tabular}

Table1 shows the summary of descriptive statistics of the measured soil properties of the study area top and subsoils samples.

\section{(a)Top soil}

The top soil of study area is predominantly clay loam. The soil $\mathrm{pH}$ varies within the neutral or slightly alkaline and range between 7.33 - 7.75. The EC values were found to vary between 0.301-1.222. OC is low (mean $0.842 \pm 0.22$ ). MC range between 2.57$3.44 \%$. Average trace and heavy element concentrations decreased according to: Fe-Mn-Cr-Zn.

\section{(b)Subsoil}

The subsoil of the study area is predominantly clay loam. The soil $\mathrm{pH}$ varies within the range 7.35-7.71. The EC values were found between 0.3550.664 . OC is very low (mean $0.806 \pm$ 0.080). MC range between 0.309-3.88. Average trace and heavy element concentrations decreased according to: $\mathrm{Fe}-\mathrm{Mn}-\mathrm{Cr}-\mathrm{Zn}$.
Correlation between soil trace and heavy element and $\mathrm{pH}$ and soil texture in North Darfur soils

In order to test the degree of association between trace and heavy elements and some other properties in North Darfur soils(Tables 2 ), a Pearson s correlation was carried out. Correlation coefficient ( $r$ ) was used for the investigation of statistical significant correlations at level , for $\mathrm{P}<0.05$.

\section{( a ) Topsoil}

The $\mathrm{pH}$ of these soil samples was found to be positively correlated with $\mathrm{MC}$ $(\mathrm{r}=0.697), \mathrm{Cr}(\mathrm{r}=0.884), \mathrm{Cu} \quad(\mathrm{r}=0.697)$, $\mathrm{Fe} \quad(\mathrm{r}=0.882)$, clay $(\mathrm{r}=0.092), \quad \mathrm{Co}$ $(\mathrm{r}=0.000001), \mathrm{Mn}(\mathrm{r}=0.787), \mathrm{Pb} \quad(\mathrm{r}=$ 0.807), $\mathrm{Zn}(\mathrm{r}=0.598)$, Mo $(\mathrm{r}=0.470)$, and $\mathrm{Ni}(\mathrm{r}=0.5996)$, and negatively correlated with EC,OC,silt, sand and $\mathrm{Cd}$.

\section{( b ) Subsoil}

$\mathrm{pH}$ was positively correlated with $\mathrm{Pb}$ $(\mathrm{r}=0.556), \mathrm{Zn}(\mathrm{r}=0.409)$, sand $(\mathrm{r}=0.168)$, Co $(r=0.000001), C r \quad(r=0.361), C u$ $(r=0.185), F e(r=0.183), M n(r=0.231)$, 
Mo $(r=0.054)$ and $\mathrm{Ni}(\mathrm{r}=0.196)$ and silt, $\mathrm{MC}$ and $\mathrm{Cd}$.

negatively correlated with EC, OC, clay,

Table 2. Correlation coefficients of the soil pH with the selected soil properties - top- and sub-soil

\begin{tabular}{|c|c|c|c|c|}
\hline & \multicolumn{2}{|r|}{ Topsoil } & \multicolumn{2}{|c|}{ Subsoil } \\
\hline & $\mathbf{R}$ & Correlation & $\mathbf{R}$ & Correlation \\
\hline EC & -0.415577 & -ve & -0.116031 & -ve- \\
\hline$\overline{\mathrm{OC}}$ & -0.148916 & -ve & -0.359154 & -ve \\
\hline Clay & 0.091973 & Weak +ve & -0.018204 & -ve \\
\hline Silt & -0.040732 & -ve & -0.158917 & -ve \\
\hline Sand & -0.080234 & -ve & 0.167688 & Weak +ve \\
\hline MC & 0.697346 & High +ve & -0.029582 & -ve \\
\hline $\mathbf{C d}$ & -0.59448 & -ve & -0.428389 & -ve \\
\hline Co & 0.000001 & Weak +ve & 0.000001 & Weak +ve \\
\hline $\mathrm{Cr}$ & 0.883943 & High +ve & 0.361201 & Weak +ve \\
\hline $\mathrm{Cu}$ & 0.696877 & High +ve & 0.184862 & Weak +ve \\
\hline $\mathbf{F e}$ & 0.88233 & High +ve & 0.183196 & Weak +ve \\
\hline Mn & 0.787107 & High +ve & 0.230801 & Weak +ve \\
\hline Mo & 0.469502 & Moderate +ve & 0.05385 & Weak +ve \\
\hline $\mathbf{N i}$ & 0.599638 & Moderate +ve & 0.195663 & Weak +ve \\
\hline $\mathbf{P b}$ & 0.80713 & High +ve & 0.556142 & High +ve \\
\hline $\mathbf{Z n}$ & 0.597648 & High +ve & 0.409402 & Moderate +ve \\
\hline
\end{tabular}

Correlation coefficients of the soil texture with the selected soil properties in study area.

\section{( a ) Topsoil (Table 3)}

Clay was positively correlated with Mo $(\mathrm{r}=0.598), \mathrm{Pb}(\mathrm{r}=0.552), \mathrm{Cr} \quad(\mathrm{r}=0.417)$, $\mathrm{Cu} \quad(\mathrm{r}=0.372), \mathrm{Fe}(\mathrm{r}=0.410)$ and $\mathrm{Mn}$ $(\mathrm{r}=0.421)$, $\mathrm{MC}(\mathrm{r}=0.206)$ and $\mathrm{Cd}(\mathrm{r}=$ 0.306) whereas no correlation with Co. Negatively correlated with EC, OC, Ni and $\mathrm{Zn}$.
Silt was positively correlated with $\mathrm{MC}$ $(\mathrm{r}=0.179)$ and $\mathrm{Cd}(\mathrm{r}=0.226)$, and no correlation with Co. Negatively correlated with $\mathrm{EC}, \mathrm{OC}, \mathrm{Cr}, \mathrm{Cu}, \mathrm{Fe}, \mathrm{Mn}$, $\mathrm{Mo}, \mathrm{Ni}, \mathrm{Pb}$ and $\mathrm{Zn}$.

Sand was positively correlated with EC $(\mathrm{r}=0.425)$, OC $(\mathrm{r}=0.502), \mathrm{Ni}(\mathrm{r}=0.457)$ and $\mathrm{Zn}(\mathrm{r}=0.566)$, and no correlation with Co. Negatively correlated with $\mathrm{MC}, \mathrm{Cd}, \mathrm{Cr}, \mathrm{Cu}, \mathrm{Fe}, \mathrm{Mn}, \mathrm{Mo}$ and $\mathrm{Pb}$. 
Table 3. Correlation coefficients of the soil texture with the selected soil properties - Topsoil

\begin{tabular}{|c|c|c|c|c|c|c|}
\hline & \multicolumn{2}{|c|}{ Clay } & \multicolumn{2}{|c|}{ Silt } & \multicolumn{2}{|c|}{ Sand } \\
\hline & $\mathbf{R}$ & Correlation & $\overline{\mathbf{R}}$ & Correlation & $\mathbf{R}$ & Correlation \\
\hline EC & -0.221913 & -ve & -0.402976 & -ve & 0.424873 & $\begin{array}{l}\text { Moderate } \\
\text { +ve }\end{array}$ \\
\hline OC & -0.41108 & -ve & -0.128078 & -ve & 0.501709 & $\begin{array}{l}\text { Moderate } \\
+\mathrm{ve}\end{array}$ \\
\hline MC & 0.205969 & Weak +ve & 0.17914 & Weak +ve & -0.304425 & -ve \\
\hline Cd & 0.305926 & Weak +ve & 0.225651 & Weak +ve & -0.43351 & $-\mathrm{ve}$ \\
\hline Co & 0.0 & $\begin{array}{l}\text { No } \\
\text { correlation }\end{array}$ & 0.0 & No correlation & 0.0 & $\begin{array}{l}\text { No } \\
\text { correlation }\end{array}$ \\
\hline $\mathrm{Cr}$ & 0.417367 & $\begin{array}{l}\text { Moderate } \\
+\mathrm{ve}\end{array}$ & -0.220729 & -ve & -0.347535 & -ve \\
\hline $\mathbf{C u}$ & 0.372115 & $\begin{array}{l}\text { Moderate } \\
+\mathrm{ve}\end{array}$ & -0.446523 & -ve & -0.194628 & -ve \\
\hline $\mathbf{F e}$ & 0.410288 & $\begin{array}{l}\text { Moderate } \\
+ \text { ve }\end{array}$ & -0.219025 & -ve & -0.340699 & -ve \\
\hline Mn & 0.421267 & $\begin{array}{l}\text { Moderate } \\
+ \text { ve }\end{array}$ & -0.303587 & -ve & -0.313503 & -ve \\
\hline Mo & 0.598295 & High +ve & -0.195061 & -ve & -0.554185 & -ve \\
\hline $\mathbf{N i}$ & -0.331636 & -ve & -0.215504 & -ve & 0.45651 & $\begin{array}{l}\text { Moderate } \\
\text { +ve }\end{array}$ \\
\hline $\mathbf{P b}$ & 0.55243 & High +ve & -0.295002 & -ve & -0.458688 & -ve \\
\hline $\mathbf{Z n}$ & -0.667126 & -ve & -0.460991 & -ve & 0.565504 & High +ve \\
\hline
\end{tabular}

\section{( b ) Subsoil (Table 4)}

Clay was positively correlated with $\mathrm{Cr}(0.796)$, $\mathrm{Cu}(\mathrm{r}=0.713), \mathrm{Mn}(\mathrm{r}=0.841), \mathrm{Fe}(\mathrm{r}=0.4879), \mathrm{EC}$ $(\mathrm{r}=0.1411), \mathrm{Cd}(\mathrm{r}=0.280)$, Mo $(\mathrm{r}=0.133)$ and $\mathrm{Ni} \quad(\mathrm{r}=0.275)$. No correlation with Co. Negatively correlated with $\mathrm{OC}, \mathrm{MC}, \mathrm{Pb}$ and $\mathrm{Zn}$.

Silt was positively correlated with OC ( $r=0.661)$, Mo ( $r=0.626)$, EC ( $r=0.262)$ and $\mathrm{Cd}$ $(\mathrm{r}=0.210)$, no correlation with $\mathrm{Co}$, and was negatively correlated with $\mathrm{MC}, \mathrm{Cr}, \mathrm{Cu}$, $\mathrm{Fe}, \mathrm{Mn}, \mathrm{Ni}, \mathrm{Pb}$ and $\mathrm{Zn}$.

Sand was positively correlated with $\mathrm{Ni}$ $(\mathrm{r}=0.580), \mathrm{Zn} \quad(\mathrm{r}=0.574), \mathrm{MC} \quad(\mathrm{r}=0.503), \mathrm{Fe}$ $(\mathrm{r}=0.542), \mathrm{Cr}(\mathrm{r}=0.087), \mathrm{Cu} \quad(\mathrm{r}=0.158), \mathrm{Mn}$ $(\mathrm{r}=0.013)$ and $\mathrm{Pb}(\mathrm{r}=0.293)$ and no correlation with Co. Sand was negatively correlated with $\mathrm{EC}, \mathrm{OC}, \mathrm{Cd}$ and $\mathrm{MO}$.
The soil $\mathrm{pH}$ of samples from study area was ranged from 7.529-7.464, within optimum range (5.5-8.00) considered to be satisfactory for cultivation of economic crops.

Electrical conductivity (EC) is one of the major parameter assessing the salinity status of a soil. Salinity is a problem situation in soils accumulation of excess soluble salts due to high evapotranspiration and poor drainage. Low EC values (less than $0.05 \mathrm{ds} / \mathrm{m}$ ) indicating no salinity hazard.

Organic carbon is characterized by its ability to form complexes, interact with clay minerals, bind particles together and hold water in the soil environment. As a result of these characteristics, the determination of total organic carbon is an essential part of any site characterization since its presence or absence can influence the reactivity of chemicals in the soil. 
Table 4. Correlation coefficients of the soil texture with the selected soil properties - Subpsoil

\begin{tabular}{|c|c|c|c|c|c|c|}
\hline & \multicolumn{2}{|c|}{ Clay } & \multicolumn{2}{|c|}{ Silt } & \multicolumn{2}{|c|}{ Sand } \\
\hline & $\mathbf{R}$ & Correlation & $\overline{\mathbf{R}}$ & Correlation & $\mathbf{R}$ & Correlation \\
\hline EC & 0.141145 & Weak +ve & 0.261624 & Weak +ve & -0.300504 & $-\mathrm{ve}$ \\
\hline OC & -0.722278 & -ve & 0.660557 & High +ve & -0.528765 & -ve \\
\hline MC & -0.024396 & -ve & -0.479102 & -ve & 0.502822 & $\begin{array}{l}\text { Moderate } \\
\text { +ve }\end{array}$ \\
\hline Cd & 0.280499 & Weak +ve & 0.210264 & Weak +ve & -0.27626 & -ve \\
\hline Co & 0.0 & $\begin{array}{l}\text { No } \\
\text { correlation }\end{array}$ & 0.0 & No correlation & 0.0 & $\begin{array}{l}\text { No } \\
\text { correlation }\end{array}$ \\
\hline $\mathbf{C r}$ & 0.79594 & High +ve & -0.247797 & -ve & 0.086867 & Weak +ve \\
\hline $\mathbf{C u}$ & 0.713437 & High +ve & -0.299948 & -ve & 0.158433 & Weak +ve \\
\hline $\mathbf{F e}$ & 0.487945 & $\begin{array}{l}\text { Moderate } \\
\text { +ve }\end{array}$ & -0.623058 & -ve & 0.541904 & $\begin{array}{l}\text { Moderate } \\
+ \text { ve }\end{array}$ \\
\hline Mn & 0.84089 & High +ve & -0.18618 & -ve & 0.013439 & Weak +ve \\
\hline Mo & 0.133292 & Weak +ve & 0.626347 & High +ve & -0.676477 & -ve \\
\hline $\mathbf{N i}$ & 0.274784 & Weak +ve & -0.617529 & -ve & 0.580442 & High +ve \\
\hline $\mathbf{P b}$ & -0.140949 & -ve & -0.254692 & -ve & 0.292764 & Weak +ve \\
\hline Zn & -0.146428 & -ve & -0.524053 & -ve & 0.573642 & High +ve \\
\hline
\end{tabular}

Therefore, soil organic matter is one of the key parameters determining the quality of a soil.

Soil texture has a major influence on the total concentration of selected heavy elements in soil. Analysis of study area indicates that total heavy elements content in the surface horizon of North Darfur soils is generally lowest in sandy soils and the highest in clayey soils. Specifically, total $\mathrm{Fe}, \mathrm{Cu}, \mathrm{Co}, \mathrm{Ni}$ and $\mathrm{Zn}$ concentration is strongly related to clay content.

It is clear from the data obtained in this study that the $\mathrm{Cr}$ concentration exhibits no correlation with increase or decrease of depth. The amount of $\mathrm{Cr}$ in both the layers of soils of study area are highly variable. Chromium ranging from 58.406 to 75.202.Some of the highest $\mathrm{Cr}$ contents are reported for loamy and clay soils of Chad $(100-300 \mathrm{mg} / \mathrm{kg})$, for loamy soils of New Zealand (70 $1100 \mathrm{mg} / \mathrm{kg}$ ), and for forest soils of Bulgaria $(152-384 \mathrm{mg} / \mathrm{kg})$. Swedish arable soils contain $\mathrm{Cr}$ in the range from 3 to $50 \mathrm{mg} / \mathrm{kg}$, at an average value of $22 \mathrm{mg} / \mathrm{kg}$ (Eriksson, 2001) ${ }^{9}$. Whereas the median content of Mo in Lithuanian soil is reported to be $0.62 \mathrm{mg} / \mathrm{kg}$ and does not show any distinct association with soil texture.Swedish arable soils contain Mo in the range from 0.1 to $4 \mathrm{mg} / \mathrm{kg}$, at an average value of $\quad 0.6 \quad \mathrm{mg} / \mathrm{kg}$ (Eriksson,2001). Positive correlation were found between $\mathrm{pH}$ and Mo and clay - Mo in top-soil of study area and also positive correlation was found between silt-Mo in sub-soil ( $\mathrm{r}=$ 0.626. The $90^{\text {th }}$ percentile value for Mo in Finnish soils is $1.5 \mathrm{mg} / \mathrm{kg}$ (Koljonen,1992),

Manganese content of worldwide soils vary from 411 to $550 \mathrm{mg} / \mathrm{kg}$. It highest levels occur in loamy and calcareous soils.During weathering, Mn compound are oxidize under atmosphere condition 
and release $\mathrm{Mn}$ oxides are reprecipitated and readily concentrated in forms of secondary Mn minerals. Mn content of studied area in North Darfur (508.976$636.0625 \mathrm{ppm}$ ) was higher in sub--soil . Strong positive correlation were also found between Mn-clay in sub-soils of study area(Table 1,2,5). These relationships in soil has resulted in a higher Mn content in loamy sand. The abundance of $\mathrm{Fe}$ in soils average 3.5\% and is likely to be increased in heavy loamy soils and some organic soils.

The Co content of soils is inherited mainly from parent materials. The worldwide mean value of Co in surface soils is calculated as $10 \mathrm{mg} / \mathrm{kg}$. Usually, higher levels of Co are in heavy loamy soils (Cambisols) and, sometimes, in organic soil (Histosols). The content and distribution of $\mathrm{Co}$ in soil profiles are dependent on soilforming processes and therefore differ for soils of various climatic zone. Higher Co contents of surface soils are found in arid and semiarid regions, for examples, Egyptian soils contain Co from 16.5 to $26.8 \mathrm{mg} / \mathrm{kg}$ (Nasseem and Abdalla, 2003), while low soil Co has been reported for the glaciated regions of northern parts of different continents, as well as for the atlantic Coastal plain of the United State. Swedish arable soils contain Co in the range of $0.4-14 \mathrm{mg} / \mathrm{kg}$ , at the average value of $0.7 \mathrm{mg} / \mathrm{kg}$. Surface horizons of Russian chermozems contain Co in the range of mean values from 9.2 to $10.8 \mathrm{mg} / \mathrm{kg}$ (Protasova and Kopayeva ,1985 ) ${ }^{12}$. Co contents in soils of south Africa range from 1.51 to $68.5 \mathrm{mg} / \mathrm{kg}$, with median value 8.44 and arithmetic mean 18.0 (Herselmanet al., 2005).

Co content of studied area in North Darfur (0.05 ppm) in both top and subsoil. Weak positive correlation were found between $\mathrm{Co}-\mathrm{pH}$ in both top and sub-soils and no correlation between Co and soil texture of study area(Table 1-5). Soils throughout the world contain $\mathrm{Ni}$ in the very broad range, however its mean concentrations, as reported for various countries are within the range 13-37 $\mathrm{mg} / \mathrm{kg}$. The baseline levels for $\mathrm{Ni}$ in soils of Brazil is given (in $\mathrm{mg} / \mathrm{kg}$ ) as 0.5 for sandstone soil and 11.5 for limestone soil (Melo et al., 2006). The lowest $\mathrm{Ni}$ levels $(7.6 \mathrm{mg} / \mathrm{kg})$ was in soil with $0.9 \%$ clay content, and the highest (53.8 $\mathrm{mg} / \mathrm{kg}$ ) in soil with $4.6 \%$ clay contentBettinelliet al.(2000) ${ }^{15}$. Ni content in soil from major agricultural production areas of the United States is $16.5 \mathrm{mg} / \mathrm{kg}$, in our study area was found between 10.857-22.597 ppm. Strong positive correlation were found between $\mathrm{pH}-\mathrm{Ni}$,sand-Ni in both top-soil and subsoil of study area.

$\mathrm{Cu}$ are closely associated with soil texture and usually are the lowest in light sandy soils and the highest in loamy soils. The regularity in large-scale $\mathrm{Cu}$ occurrence in soils indicated that two main factor, parent material and soil formation processes, govern the initial $\mathrm{Cu}$ status of soils. Also, the clay fraction contributes significantly to the $\mathrm{Cu}$ contents of soils. The baseline levels for $\mathrm{Cu}$ in soils of Brazil is given (in $\mathrm{mg} / \mathrm{kg}$ ) as 1.0 and 8.7 for sandstone and limestone soils, respectively (Melo et al., 2006). The concentration of $\mathrm{Cu}$ in 3045 samples of surface soil from major agriculture production areas of the United State was found $18 \mathrm{mg} / \mathrm{kg}$.It is clear from the data drawn in this study, there is no systematic increase or decrease of $\mathrm{Cu}$ with the increase or decrease of depth. The $\mathrm{Cu}$ concentration in soils of study area in range between 23.61-29.645. The increase of the $\mathrm{Cu}$ concentration in the soils can be 
attributed to the weathering of sulfides in the surrounding mountains areas around the region.

\section{Conclusion}

The physico-chemical analysis of soil samples under study showed variable concentration of various parameters. The data from this study provide background levels for selected heavy elements in relation to physico-chemical parameters in North Darfur soils.

Levels of trace and heavy elements studied are generally within the range for soils on a world-wide basis. Some trace elements examined in this study that are potentially may toxic to biological systems and therefore of environmental concern are within reported levels of acceptability.

The heavy elements detected in sampling study area could contaminate surface and ground water. Hence, steps should be taken to check the flow and accumulation of these heavy elements to avoid any harm to human existence.

This study provides a comprehensive investigation of the contents of trace and heavy metals in soils in North Darfur ; however, $\mathrm{Fe}, \mathrm{Cr}$ and $\mathrm{Cu}$ were very high. This study will help the industrial section and can be benefit from it for commercial purposes.

\section{Acknowledgement.}

The authors extend their appreciation to the Department of Chemistry, Faculty of Science and Technology, Omdurman Islamic University for providing laboratory facilities and assistance. Particular thank to Ministry of Higher Education and Scientific Research for financial support. Special thanks are also extended to Faculty of Education, EL-
Fashir University for their help and support.

\section{References}

Allen, S.E. (ed.), 1974. Chemical Analysis of Ecological Materials. Blackwell, Oxford. ISBN-13:9780632017423.

Bettinelli M., Baffi C., Beone G.M., Spezia S. 2000. Soil and sediment analyses by spectroscopic techniques. Part I: determination of $\mathrm{Cd}, \mathrm{Co}, \mathrm{Cr}, \mathrm{Cu}$, $\mathrm{Mn}, \mathrm{Pb}$, and $\mathrm{Zn}$. Atomic Spectrosc. 21:50-5. Perkin Elmer.

Black, C.A. (ed.) (1965). Methods of Soil and Plant Analyses. Agron. No.9 Part 2 Amer.Soc.Madison.

Eriksson J.E. 2001. Concentrations of 61 trace elements in sewage sludge, farmyard manure, mineral fertiliz-ers, precipitation and in oil and crops. Swedish EPA. Rep 5159. Stockholm.

Herselman J.E., Steyn C.E., Fey M.V. 2005. Baseline concentration of $\mathrm{Cd}, \mathrm{Co}$, $\mathrm{Cr}, \mathrm{Cu}, \mathrm{Pb}, \mathrm{Ni}$ and $\mathrm{Zn}$ in surface soils of South Africa. South African J. Sci. 101:509-512.

Kaur M., Soodan PK, Katnoria JK, Bhardwaj R, Pakade YB, Nagpal AV (2014). Analysis of physicochemical parameters, genotoxicity and oxidative stress inducing potential of soils of some agricultural fields under rice cultivation. Tropical Plant Research 1(3):49-61.

Koljonen, T. (1992). The Geochemical Atlas Finland, Part 2: Till, Geol. Survey of Finland, Espoo, 1992.

Melo Jr. G., Carvalho F.B., Nogueira M.L.S., et al. 2006. Baseline levels for selected elements in soils under semiarid condition, northeast of Brazil. Geophys. Res. Abstracts, EGU 8:07331. In: Trace Elements in Soils and Plants. $3^{\text {rd }}$ Edition. Kabata - Pendias A. https://books.google.com. 
Nasseem M.G., Abdalla Y.H. 2003. Cobalt status in the North Western Coast Soils of Egypt in relation to cobalt content of barley for ruminants. 16 Int. Symp. Environ. Biogeochem. Edinburgh.

Protasova, N. A. and Kopayeva, M. T. (1985). Trace and dispersed elements in soils of Russian Plateau, Pochvovedenie, $1,29$.

Piper,C.S. (1950). Soil and Plant Analysis. Adelaide University.

Rayment GE, Jeffery AJ, Barry GA (2002). Heavy metals in Australian sugarcane. Contaminations in Soil Science and Plant Analysis. 33:15-18, 3203-3212.

Richards L.A. (ed.), (1954). Diagnosis and improvement of saline and alkali soils. US Dept. Agr.Handbook 60. US Gov. Printing Office. Washington, DC.

Sinha S, Gupta AK, Bhatt K, Pandey K, Rai UN, Singh KP (2006). Distribution of metals in the edible plants grown at Jajmau , Kanpur (India) receiving treated tannery wastewater : Relation with physicochemical properties of soil. Environmental Monitoring and Assessment 115: 1-22.

Forest Service Handbook. Washington, DC, 1960, Department of Agriculture , US 